\title{
The Second Galanin Receptor GalR2 Plays a Key Role in Neurite Outgrowth from Adult Sensory Neurons
}

\author{
Sally-Ann Mahoney, ${ }^{1}$ Richard Hosking, ${ }^{1}$ Sarah Farrant, ${ }^{1}$ Fiona E. Holmes, ${ }^{1}$ Arie S. Jacoby, ${ }^{2}$ John Shine, ${ }^{2}$ \\ Tiina P. Iismaa, ${ }^{2}$ Malcolm K. Scott, ${ }^{3}$ Ralf Schmidt, ${ }^{4}$ and David Wynick ${ }^{1}$ \\ ${ }^{1}$ University Research Centre for Neuroendocrinology, Bristol University, Bristol BS2 8HW, United Kingdom, ${ }^{2}$ The Garvan Institute of Medical Research, \\ Sydney, NSW 2010, Australia, ${ }^{3}$ Johnson \& Johnson Pharmaceutical Research Institute, Spring House, Pennsylvania 19477-0776, and ${ }^{4}$ AstraZeneca R\&D \\ Montreal, Montreal, Quebec H4S 1Z9, Canada
}

Expression of the neuropeptide galanin is markedly upregulated within the adult dorsal root ganglion (DRG) after peripheral nerve injury. We demonstrated previously that the rate of peripheral nerve regeneration is reduced in galanin knock-out mice, with similar deficits observed in neurite outgrowth from cultured mutant DRG neurons. Here, we show that the addition of galanin peptide significantly enhanced neurite outgrowth from wild-type sensory neurons and fully rescued the observed deficits in mutant cultures. Furthermore, neurite outgrowth in wild-type cultures was reduced to levels observed in the mutants by the addition of the galanin antagonist M35 [galanin(1-13)bradykinin(2-9)]. Study of the first galanin receptor (GalR1) knock-out animals demonstrated no differences in neurite outgrowth compared with wild-type animals. Similarly, use of a GalR1-specific antagonist had no effect on neuritogenesis. In contrast, use of a GalR2-specific agonist had equipotent effects on neuritogenesis to galanin peptide, and inhibition of PKC reduced neurite outgrowth from wild-type sensory neurons to that observed in galanin knock-out cultures. These results demonstrate that adult sensory neurons are dependent, in part, on galanin for neurite extension and that this crucial physiological process is mediated by activation of the GalR2 receptor in a PKC-dependent manner.

Key words: galanin; GalR2; dorsal root ganglion; neuritogenesis; nerve injury; protein kinase C

\section{Introduction}

To date, the mechanisms and factors that regulate the regeneration of sensory neurons in the adult after peripheral nerve injury remain poorly understood. Damage to a peripheral nerve causes major changes within the cell bodies of the sensory neurons [dorsal root ganglion (DRG)], which are thought to promote regeneration by stimulating neurite outgrowth and enhancing survival of the damaged neuron. Furthermore, injury alters the retrograde flow of target-derived factors to the DRG. Examples of such phenomena include (1) the 120-fold upregulation in the levels of the neuropeptide galanin in the DRG after injury (Hokfelt et al., 1987) and (2) the marked increase in expression of the cytokines leukemia inhibitory factor (LIF) (Banner and Patterson, 1994; Dowsing et al., 1999) and interleukin 6 (IL-6) (Murphy et al., 1995) within Schwann cells at the site of injury and their retrograde transport to the DRG (Curtis et al., 1994). IL-6 and LIF have both been shown to promote axonal regeneration in the adult (Cheema et al., 1994; Hirota et al., 1996; Tham et al., 1997; Cafferty et al., 2001), and IL-6 knock-out mice have deficits in peripheral nerve regeneration after a crush injury to the sciatic nerve (Zhong et al., 1999). Recent data would indicate that LIF and IL-6 (acting through the gp130 coreceptor) may play a role in both injury-induced regeneration and minimizing pathological

Received July 19, 2002; revised 0ct. 16, 2002; accepted 0ct. 30, 2002.

This work was supported by the Medical Research Council, the Wellcome Trust, National Health and Medical Research Council (Australia), and a Human Science Program short-term fellowship.

Correspondence should be addressed to Prof. David Wynick, University Research Centre for Neuroendocrinology, Bristol University, Marlborough Street, Bristol BS2 8HW, UK. E-mail: d.wynick@bristol.ac.uk.

Copyright $\odot 2003$ Society for Neuroscience $\quad 0270-6474 / 03 / 230416-06 \$ 15.00 / 0$ nociceptive responses by positively regulating the expression of galanin in the DRG (Corness et al., 1996; Thompson et al., 1998).

In the adult, galanin is expressed at low levels in $<5 \%$ of DRG cells, which are predominantly the small peptidergic C-fiber neurons (Hokfelt et al., 1987). After nerve injury, there is a rapid and robust upregulation of both galanin mRNA and peptide, and expression of the peptide is now observed in $40-50 \%$ of all DRG neurons (Villar et al., 1989; Hokfelt et al., 1994). Studies indicate that galanin reduces transmission of sensory information in the spinal cord after nerve injury (Wiesenfeld-Hallin et al., 1989, 1992; Verge et al., 1993). In addition, rising levels of galanin in sensory neurons may also contribute to the initiation and maintenance of axonal regeneration in the injured neurons, leading to functional recovery and restoration of function while minimizing pathological nociceptive responses.

We showed previously that cultured DRG cells from animals homozygous for a targeted mutation in the galanin gene have a $35 \%$ reduction in the length of neurites and number of cells that extend neurites (Holmes et al., 2000). In this study, we used a combination of pharmacological and genetic tools to further elucidate the mechanisms by which galanin regulates neuritogenesis. Here, we show that galanin plays a neuritogenic role in adult sensory neurons and rescues the deficits in neurite outgrowth seen in mutant cultures. Furthermore, we demonstrate that its actions are mediated by the second galanin receptor (GalR2) in a PKC-dependent manner.

\section{Materials and Methods \\ Animals \\ Galanin knock-out mice. Experiments were performed on 8-week-old female mice homozygous for a targeted mutation in the galanin gene.}


Age-matched wild-type littermates were used as controls in all experiments. Details of the strain and breeding history have been published previously (Wynick et al., 1998; Kerr et al., 2000). In brief, galanin knockout mice were generated using the E14 cell line. A PGK-Neo cassette in reverse orientation was used to replace exons $1-5$, and the mutation was bred to homozygosity and has remained inbred on the 129olaHsd strain. All animals were fed standard chow and water ad libitum. Animal care and procedures were performed within United Kingdom Home Office protocols and guidelines.

GalR1 knock-out mice. Experiments were performed on 8-week-old female mice that carry an insertional inactivating mutation within the first exon of the gene encoding the murine GalR1. Age-matched wildtype littermates were used as controls. In brief, GalR1 knock-out mice were generated using the W9.5 cell line and have remained inbred on the 129T2/SvEmsJ strain (Jacoby et al., 2002). All animals were fed standard chow and water ad libitum. Animal care and procedures were performed according to the Code of Practice of the Australian National Health and Medical Research Council.

\section{DRG culture}

Cultures were performed as described previously (Holmes et al., 2000). In brief, animals were killed by cervical dislocation, and DRGs from the lumbar, thoracic, and cervical regions were removed aseptically, trimmed of connective tissue and nerve roots, and pooled in DMEM-F12 medium. Ganglia were subjected to $0.25 \%$ collagenase $\mathrm{P}$ for $1 \mathrm{hr}$ at $37^{\circ} \mathrm{C}$, washed in PBS, and treated enzymatically with trypsin-EDTA for $10 \mathrm{~min}$ at $37^{\circ} \mathrm{C}$. Ganglia were washed in medium containing trypsin inhibitor and then mechanically dissociated by trituration using a flame-narrowed Pasteur pipette. After centrifugation, cells were resuspended in DMEMF12 medium supplemented with 5\% horse serum, $1 \mathrm{~mm}$ glutamine, and $10 \mathrm{ng} / \mathrm{ml}$ gentamycin. To enhance the cultures for neurons and eliminate much of the cellular debris, cells were plated on six-well plates coated with $0.5 \mathrm{mg} / \mathrm{ml}$ polyornithine and maintained overnight at $37^{\circ} \mathrm{C}$ in a humidified incubator with $95 \%$ air-5\% $\mathrm{CO}_{2}$ (Patrone et al., 1999). Medium was removed and discarded. The neurons were removed from the surface by squirting with a jet of fresh medium. After centrifugation, cells were plated on 24 -well plates treated with $0.5 \mathrm{mg} / \mathrm{ml}$ polyornithine and 5 $\mu \mathrm{g} / \mathrm{ml}$ laminin and maintained for $8 \mathrm{hr}$ at $37^{\circ} \mathrm{C}$ in a humidified incubator with $95 \%$ air $-5 \% \mathrm{CO}_{2}$.

\section{Treatments}

Cells were cultured in DMEM-F12-supplemented medium as described above with or without the addition of the following chemicals: $1 \mathrm{nM}$ M35 [galanin(1-13)bradykinin(2-9)] (Bachem UK, Essex, UK), $100 \mathrm{~nm}$ galanin peptide (Bachem UK), $10 \mu \mathrm{M}$ bisindolylmaleimide I (BIM) (Calbiochem, La Jolla, CA), 10 nм RWJ-57408 [2,3-dihydro-2-(4-methyl-phenyl)1,4-dithiepine-1,1,4,4-tetroxide] (Johnson \& Johnson, Spring House, PA), and $100 \mathrm{~nm}$ AR-M961 ([Sar(1), D-Ala $\left.{ }^{12}\right] \mathrm{Gal}(1-16)-\mathrm{NH}_{2}$ ) or AR-M1896 [Gal(2-11)Trp-Thr-Leu-Asn-Ser-Ala-Gly-Tyr-Leu-Leu-NH ${ }_{2}$ ] AstraZeneca, Montreal, Quebec, Canada).

\section{Data analysis}

Cultures were washed with PBS and fixed with $4 \%$ paraformaldehyde for $20 \mathrm{~min}$ at room temperature. Cells were visualized by phase-contrast microscopy. The percentage of cells bearing neurites and neurite length were both measured using NIH Image (Scion, Frederick, MD). Data are presented as mean \pm SEM.

\section{Results}

\section{Galanin signaling mediates neurite outgrowth}

The addition of $100 \mathrm{~nm}$ galanin to wild-type adult DRG cells significantly increased the length of neurites (Fig. $1 B$ ), whereas the percentage of cells producing neurites was unchanged (Fig. $1 A)$, suggesting that the number of cells capable of extending neurites was already at maximum under these culture conditions. Addition of $100 \mathrm{~nm}$ galanin peptide to mutant cultures fully rescued the deficits in the percentage of cells producing neurites and restored neurite length to wild-type levels.

We substantiated this putative neuritogenic role in the adult
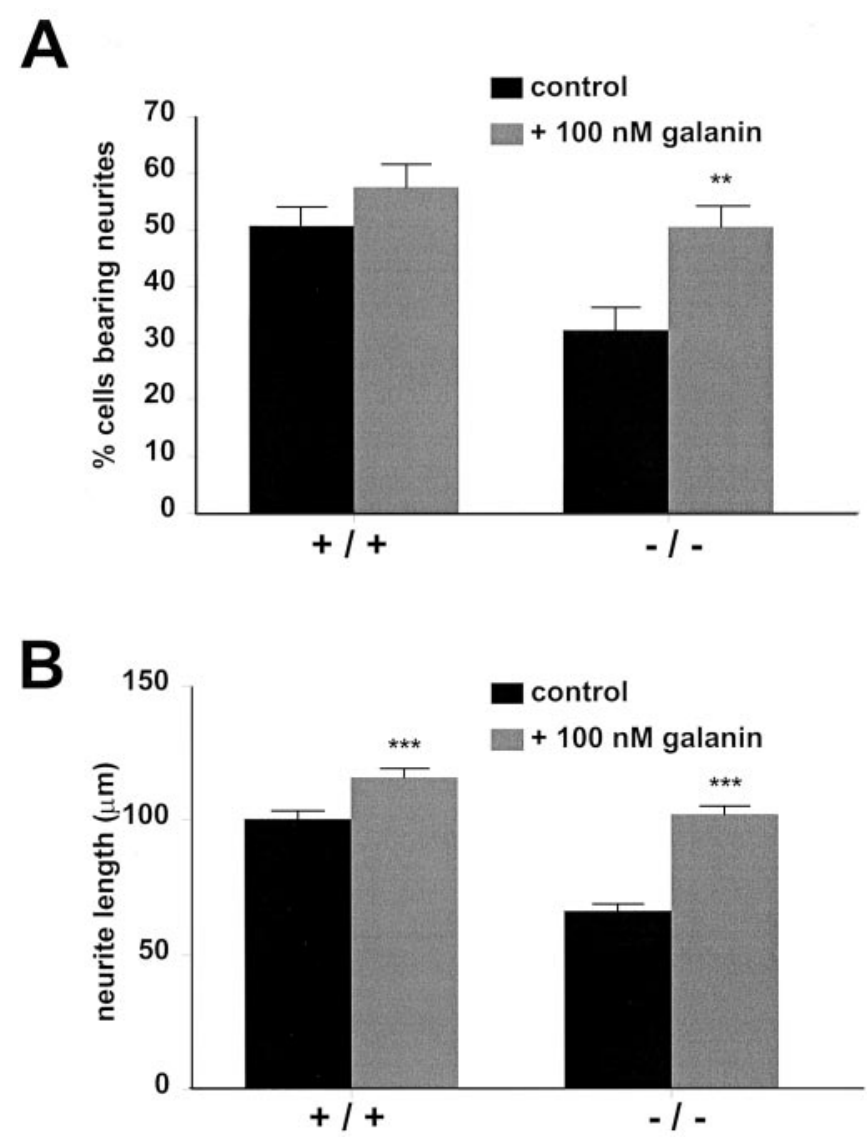

Figure 1. The percentage of cells bearing neurites $(A)$ and length of neurite outgrowth $(B)$ from dissociated DRG cultures isolated from wild-type and galanin knock-out animals in the presence and absence of $100 \mathrm{~nm}$ galanin peptide $8 \mathrm{hr}$ after plating. Addition of $100 \mathrm{~nm}$ galanin to wild-type cultures significantly increased neurite length, whereas there was no significant difference in the percentage of cells producing neurites. However, addition of $100 \mathrm{~nm}$ galanin to galanin knock-out cultures significantly increased both the percentage of cells producing neurites and the length of neurites. Data are presented as percentage of cells bearing neurites or mean \pm SEM length ( $t$ test; ${ }^{* *} p<0.01 ;{ }^{* * *} p<0.001 ; n=5$ ).

further by using the potent galanin antagonist M35 (Bartfai et al., 1992), which acts at all known galanin receptor subtypes (Wiesenfeld-Hallin et al., 1993). The addition of $1 \mathrm{~nm} \mathrm{M35}$ to wild-type cultures produced a significant 35\% reduction in both the percentage of cells bearing neurites (Fig. 2A) and neurite length (Fig. $2 B$ ) to levels observed in mutant cultures. No effect was seen on either parameter in mutant cultures. This dose of M35 has been shown previously to have purely antagonistic effects (Wiesenfeld-Hallin et al., 1992; Ogren et al., 1993).

The neuritogenic role of galanin is not mediated by GalR1

To determine whether the GalR1 receptor subtype is important in mediating the neuritogenic effects of galanin, we first used the small-molecule, nonpeptide GalR1-specific antagonist RWJ-

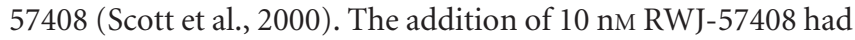
no effect on the percentage of cells bearing neurites in either wild-type or mutant cultures (Fig. $3 A$ ). Similar results were seen with the addition of $1 \mathrm{nM}$ RWJ-57408 (data not shown).

To study the role of GalR1 in mediating neuritogenesis further, we studied neurite outgrowth in GalR1 knock-out mouse dissociated DRG cultures (Jacoby et al., 2002). No differences were observed in the percentage of GalR1 mutant cells bearing neurites compared with those from wild-type controls (Fig. 3B). 

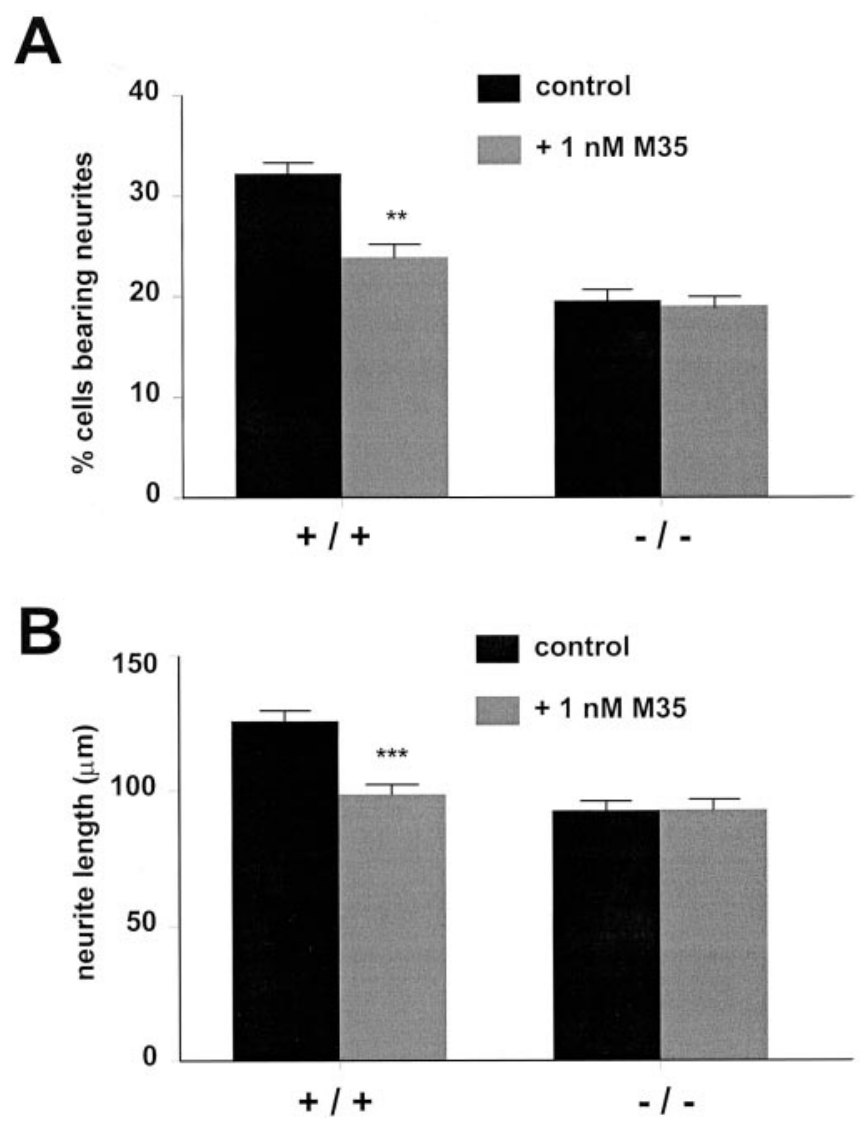

Figure 2. The percentage of cells bearing neurites $(A)$ and length of neurite outgrowth $(B)$ from dissociated DRG cultures isolated from wild-type and galanin knock-out animals in the presence and absence of $1 \mathrm{~nm} \mathrm{M35} 8 \mathrm{hr}$ after plating. In both cases, significant deficits were noted in the wild-type cultures, whereas no effect was seen in the knock-out cultures. Data are presented as percentage of cells bearing neurites or mean \pm SEM length $\left(t\right.$ test; ${ }^{* *} p<0.01$; $\left.{ }^{* * *} p<0.001 ; n=5\right)$.

Furthermore, there was no significant difference in neurite length between cells from wild-type controls $(140.8 \pm 9 \mu \mathrm{m})$ and GalR1 mutant cells (161.6 $\pm 8 \mu \mathrm{m})$.

\section{The neuritogenic role of galanin is mediated by GalR2 in a PKC-dependent manner}

We next studied whether GalR2 might be responsible for transducing the neuritogenic actions of galanin by using the newly described peptide analog AR-M1896, a selective GalR2 agonist (Liu et al., 2001). In addition, we studied the actions of AR-M961, which has been shown to have agonistic actions at both GalR1 and GalR2 subtypes (Liu et al., 2001). The addition of $100 \mathrm{~nm}$ AR-M1896 or AR-M961 fully rescued the deficits in percentage outgrowth seen in the mutant cultures to wild-type levels (Fig. $4 A$ ) and appeared to be equipotent to galanin (Fig. 1A). Similarly, the addition of either AR-M961 or AR-M1896 to wild-type cultures increased both the percentage of cells bearing neurites and neurite length to the same extent as that observed with galanin peptide (Fig. $4 A, B$ ).

To investigate whether the neuritogenic role of galanin was PKC dependent, we used the PKC-specific inhibitor bisindolylmaleimide I (GF109203X) (Rivera-Bermudez et al., 2002). Addition of $10 \mu \mathrm{M}$ BIM to wild-type cultures significantly reduced the percentage of cells bearing neurites to the levels observed in galanin knock-out cultures; similar results were seen using $1 \mu \mathrm{M}$ BIM (data not shown). Furthermore, $10 \mu \mathrm{M}$ BIM completely
A

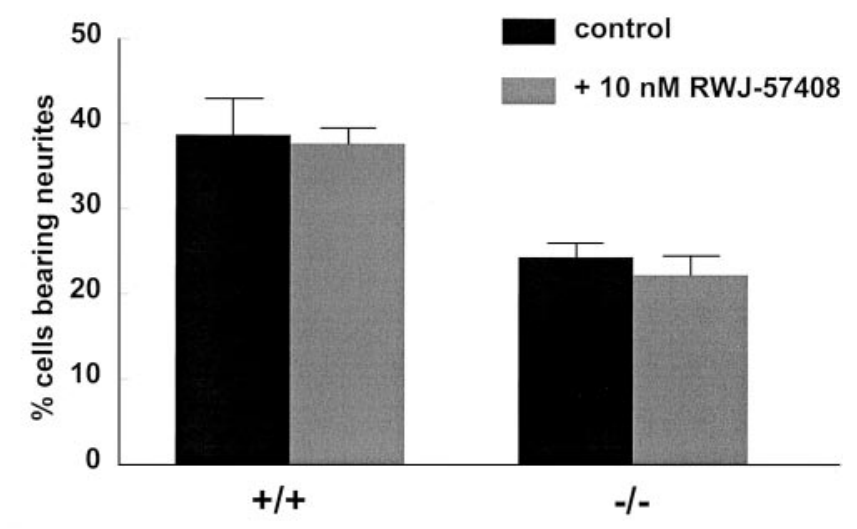

B

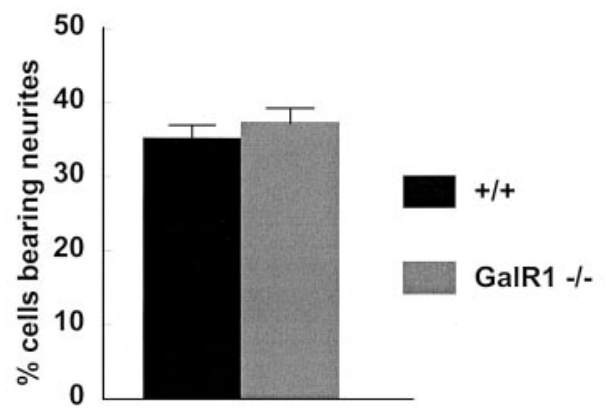

Figure 3. A, The percentage of cells bearing neurites from dissociated DRG cultures isolated from wild-type and galanin knock-out animals in the presence and absence of $10 \mathrm{~nm}$ RWJ-57408 $8 \mathrm{hr}$ after plating. $B$, The percentage of cells bearing neurites from dissociated DRG cultures isolated from wild-type and GalR1 knock-out animals $8 \mathrm{hr}$ after plating. Data are presented as percentage of cells bearing neurites $\pm \operatorname{SEM}(n=5)$.

abolished the stimulatory neuritogenic actions of $100 \mathrm{nM}$ ARM1896 on both wild-type and mutant cultures (Fig. 4C).

\section{Discussion}

Damage to a peripheral nerve induces major and long-lasting changes in the expression of many secreted ligands and their receptors within the sensory neurons of the DRG. One of the most striking changes that occurs is the 120-fold increase in the expression of the neuropeptide galanin. We showed recently that galanin plays an important role in the survival of a subset of DRG neurons (Holmes et al., 2000), with a 2.8- and 2.6-fold increase in the number of apoptotic cells in the DRG of galanin knock-out mice at postnatal day $3(\mathrm{P} 3)$ and $\mathrm{P} 4$, respectively, compared with wild-type controls. This wave of apoptosis at P3 is associated with a $13 \%$ decrease in total cell number within the DRG (Holmes et al., 2000). The role of galanin in cell survival is further substantiated by the finding that galanin is essential for the developmental survival of one-third of the cholinergic neurons of the basal forebrain (O’Meara et al., 2000).

The role played by galanin in the survival of this subset of DRG neurons seems to be preferentially biased toward the small peptidergic neurons, which are most likely to be nociceptors (Holmes et al., 2000). The loss of these small unmyelinated neurons may provide an explanation for the finding that galanin knock-out animals demonstrate a decrease in chronic neuropathic pain behavior after nerve injury (Kerr et al., 2000). Many of the animal models of peripheral nerve injury that induce neuropathic pain behavior are also associated with an upregulation 

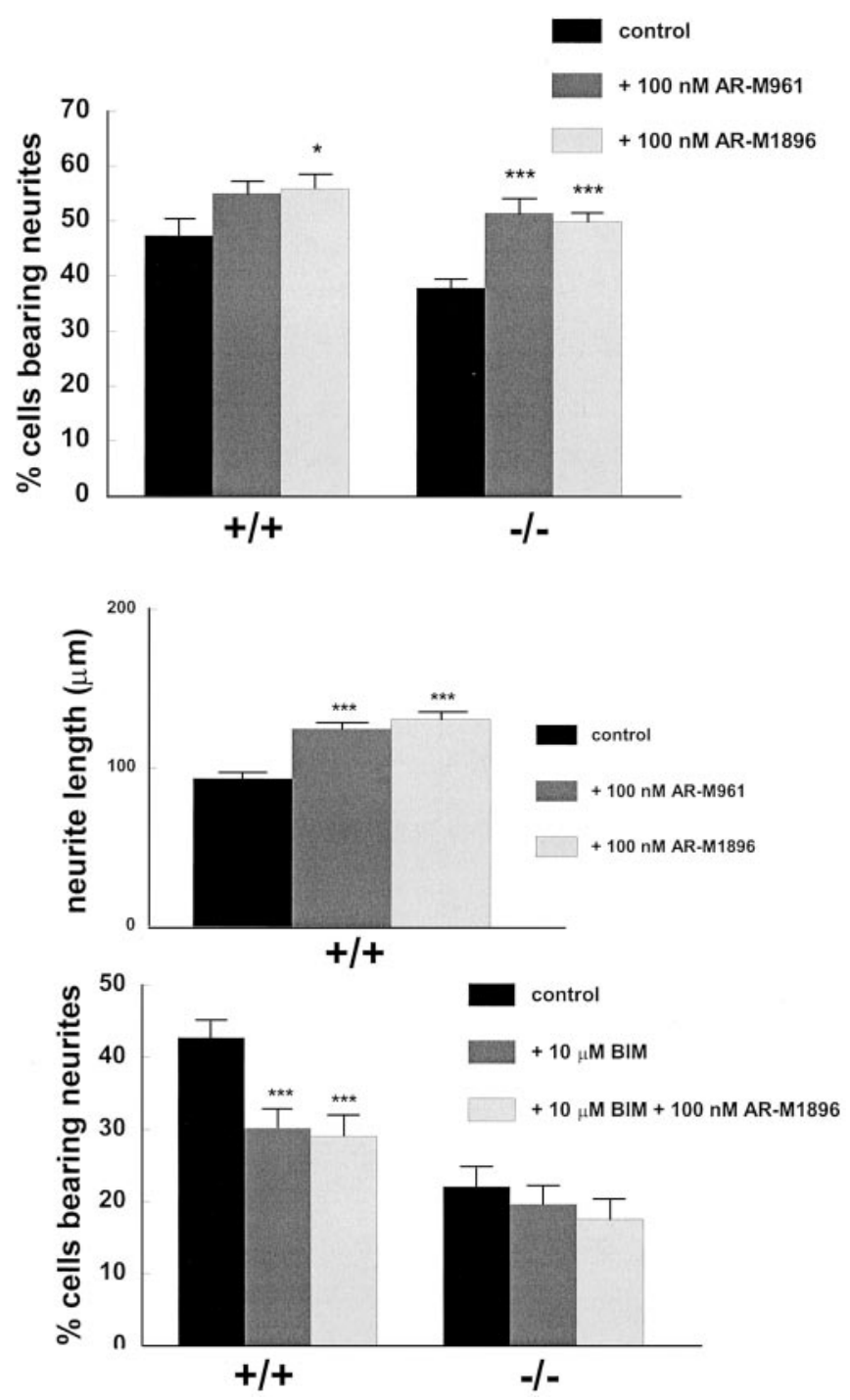

Figure 4. A, The percentage of cells bearing neurites from dissociated DRG cultures isolated from wild-type and galanin knock-out animals in the presence and absence of $100 \mathrm{~nm}$ AR-M961 or AR-M1896 $8 \mathrm{hr}$ after plating. The addition of either AR-M961 or AR-M1896 rescued the deficits in percentages of cells producing neurites seen in galanin knock-out cultures to near wild-type levels. Addition of AR-M1896 to wild-type cultures significantly increased the percentage of cells bearing neurites compared with controls. Although addition of AR-M961 increased the percentage, this was not significant. $B$, The length of neurite outgrowth from dissociated DRG cultures isolated from wild-type animals in the presence and absence of $100 \mathrm{nM}$ AR-M961 or AR-M18968 hr after plating. Addition of either AR-M961 or AR-M1896 significantly increased neurite length. $C$, The percentage of cells bearing neurites from dissociated DRG cultures isolated from wild-type and galanin knock-out animals in the presence and absence of $10 \mu \mathrm{M}$ BIM or $10 \mu \mathrm{m}$ BIM plus AR-M1896. Significant deficits are seen in the number of cells producing neurites in wild-type cultures in the presence of $10 \mu \mathrm{M}$ BIM, which was not rescued by the addition of $100 \mathrm{~nm}$ AR-M1896. Addition of $10 \mu \mathrm{M}$ BIM had no effect on mutant cultures. Data are presented as percentage of cells bearing neurites or mean \pm SEM length $\left(t\right.$ test; ${ }^{*} p<$ $\left.0.05 ;{ }^{* * *} p<0.001 ; n=5\right)$.

in galanin within the DRG neurons (Hokfelt et al., 1987; Villar et al., 1989; Nahin et al., 1994; Ma and Bisby, 1997). Furthermore, there appears to be a direct correlation between the extent and duration of pain behavior and the level of galanin upregulation (Ma and Bisby, 1997; Murphy et al., 1999).

The data presented here using galanin peptide or the potent galanin antagonist M35, which acts at all known galanin receptor subtypes (Wiesenfeld-Hallin et al., 1993), demonstrates that galanin is acting as a neuritogenic factor in the adult. Approxi- mately one-third of neurite outgrowth in DRG cultures is dependent on the tonic release of galanin, implying that the developmental trophic-survival role is recapitulated in the adult after injury. At present, it is not possible to state whether there is a definite relationship between the early postnatal loss of a subset of small peptidergic neurons in the galanin knock-out animals and the reduced rate of neurite outgrowth in dispersed DRG cultures isolated from adult galanin knock-out animals. However, the finding that the deficits in neurite outgrowth that we identified in the adult galanin knock-outs are fully rescued by the addition of exogenous galanin would imply that the effects in the adult are independent of the developmental loss.

To date, three G-protein-coupled galanin receptor subtypes have been identified. GalR1 is expressed in the large-diameter neurons of the DRG, and GalR2 is expressed predominantly by the small- and medium-sized neurons. Only 5\% of DRG neurons appear to express both receptor subtypes (Sten Shi et al., 1997). There have been contradictory reports as to whether GalR3 is expressed at all within the DRG. Studies using solution hybridization-RNase protection assays suggested that GalR3 is expressed at very low levels (Waters and Krause, 2000). However, other studies, again using solution hybridization-RNase protection assay (Smith et al., 1998), show no GalR3 present within the DRG; furthermore, no GalR3 has been detected in the DRG using riboprobe in situ hybridization (Mennicken et al., 2001). It is therefore unlikely that GalR3 plays a major role in neuritogenesis in the DRG.

Here, we demonstrate that addition of the small-molecule, nonpeptide GalR1-specific antagonist RWJ-57408 had no effect on neurite outgrowth in either wild-type or mutant cultures, suggesting that the role of galanin in neuritogenesis is not mediated via the GalR1 receptor subtype. This finding was substantiated by the finding that there was no difference in neurite outgrowth from GalR1 knock-out mice compared with wild-type controls. Furthermore, recent data using two separate in vivo models show that peripheral nerve regeneration is unaffected in GalR1 knockout animals (Jacoby et al., 2002). These data therefore suggest that GalR1 does not mediate the neuritogenic or proregenerative effects of galanin in the DRG, implying that GalR2 is the predominant effector.

In this study, we used the galanin receptor agonists AR-M1896 and AR-M961 (Liu et al., 2001; Ma et al., 2001). AR-M1896 is a GalR2-specific agonist with an $\mathrm{IC}_{50}$ of $1.76 \mathrm{~nm}$ at rat GalR2 and $879 \mathrm{nM}$ at human GalR1, whereas AR-M961 has been shown to have agonistic activity at both GalR2 and GalR1, with an $\mathrm{IC}_{50}$ of $1.74 \mathrm{~nm}$ and $0.403 \mathrm{nM}$, respectively (Liu et al., 2001). The data presented here demonstrate that both AR-M961 and AR-M1896 have positive effects on neuritogenesis and fully rescued deficits seen in the mutant cultures. Because our experiments using RWJ57408 and GalR1 knock-out animals indicate that neurite outgrowth is not mediated via the GalR1 receptor, the agonistic action of AR-M961 on neurite outgrowth must be caused by activation of the GalR2 subtype, which is confirmed by the actions of the GalR2-specific agonist AR-M1896 (Liu et al., 2001).

The binding of galanin to GalR1 and GalR3 inhibits adenylyl cyclase (Habert-Ortoli et al., 1994; Smith et al., 1998; Wang et al., 1998), whereas binding to GalR2 stimulates principally phospholipase C activity (Fathi et al., 1997; Howard et al., 1997; Wang et al., 1997). Studies have shown that the G-protein-coupling profiles of GalR1 and GalR2 are distinct. GalR1 couples only to $G_{i}$, whereas GalR2 couples to $G_{i}, G_{o}$, and $G_{q}$ (Wang et al., 1998). The $\mathrm{G}_{\mathrm{i}}$-mediated pathway is independent of PKC activity. In contrast, both the $\mathrm{G}_{\mathrm{o}}$ - and $\mathrm{G}_{\mathrm{q}}$-mediated mitogen-activated protein kinase 
signaling pathways are dependent on PKC activity (Hawes et al., 1996). Here, we demonstrate by use of the PKC-specific inhibitor BIM that the neuritogenic action of galanin is PKC dependent, which is consistent with activation of either the $\mathrm{G}_{\mathrm{o}^{-}}$or $\mathrm{G}_{\mathrm{q}^{-}}$ mediated signaling pathways.

In summary, these results show that galanin is an important factor in neurite extension of adult sensory neurons and that this process is mediated by activation of GalR2 in a PKC-dependent manner. The role of GalR2 as a mediator of the proliferative effect of galanin is substantiated by previous findings in small-cell lung cancer cells (Wittau et al., 2000) and the pituitary (Wynick et al., 1993, 1998). Furthermore, previous studies have shown that the antiallodynic effect of galanin on neuropathic pain is mediated via GalR1 (Liu et al., 2001), whereas here we show that the neuritogenic role of galanin is mediated via GalR2. These results suggest that different receptor subtypes may be responsible for mediating the differing physiological roles of galanin in the adaptive response of the PNS to injury. Although few data are available on human galanin expression, it appears to have an expression pattern in the DRG similar to that of the rodent (Marti et al., 1987; Suburo et al., 1992). These findings have important implications for the potential therapeutic treatment of some peripheral sensory neuropathies by the use of selective GalR2 agonists.

\section{References}

Banner LR, Patterson PH (1994) Major changes in the expression of the mRNAs for cholinergic differentiation factor/leukemia inhibitory factor and its receptor after injury to adult peripheral nerves and ganglia. Proc Natl Acad Sci USA 91:7109-7113.

Bartfai T, Fisone G, Langel U (1992) Galanin and galanin antagonists: molecular and biochemical perspectives. Trends Pharmacol Sci 13:312-317.

Cafferty WB, Gardiner NJ, Gavazzi I, Powell J, McMahon SB, Heath JK, Munson J, Cohen J, Thompson SW (2001) Leukemia inhibitory factor determines the growth status of injured adult sensory neurons. J Neurosci 21:7161-7170

Cheema SS, Richards L, Murphy M, Bartlett PF (1994) Leukemia inhibitory factor prevents the death of axotomised sensory neurons in the dorsal root ganglia of the neonatal rat. J Neurosci Res 37:213-218.

Corness J, Shi TJ, Xu ZQ, Brulet P, Hokfelt T (1996) Influence of leukemia inhibitory factor on galanin/GMAP and neuropeptide $\mathrm{Y}$ expression in mouse primary sensory neurons after axotomy. Exp Brain Res 112:79-88.

Curtis R, Scherer SS, Somogyi R, Adryan KM, Ip NY, Zhu Y, Lindsay RM, DiStefano PS (1994) Retrograde axonal transport of LIF is increased by peripheral nerve injury: correlation with increased LIF expression in distal nerve. Neuron 12:191-204.

Dowsing BJ, Morrison WA, Nicola NA, Starkey GP, Bucci T, Kilpatrick TJ (1999) Leukemia inhibitory factor is an autocrine survival factor for Schwann cells. J Neurochem 73:96-104.

Fathi Z, Cunningham AM, Iben LG, Battaglino PB, Ward SA, Nichol KA, Pine KA, Wang J, Goldstein ME, Iismaa TP, Zimanyi IA (1997) Cloning, pharmacological characterization and distribution of a novel galanin receptor. Brain Res Mol Brain Res 51:49-59.

Habert-Ortoli E, Amiranoff B, Loquet I, Laburthe M, Mayaux JF (1994) Molecular cloning of a functional human galanin receptor. Proc Natl Acad Sci USA 91:9780-9783.

Hawes BE, Luttrell LM, van Biesen T, Lefkowitz RJ (1996) Phosphatidylinositol 3-kinase is an early intermediate in the G beta gamma-mediated mitogen-activated protein kinase signaling pathway. J Biol Chem 271:12133-12136.

Hirota H, Kiyama H, Kishimoto T, Taga T (1996) Accelerated nerve regeneration in mice by upregulated expression of interleukin (IL) 6 and IL-6 receptor after trauma. J Exp Med 183:2627-2634.

Hokfelt T, Wiesenfeld-Hallin Z, Villar M, Melander T (1987) Increase of galanin-like immunoreactivity in rat dorsal root ganglion cells after peripheral axotomy. Neurosci Lett 83:217-220.

Hokfelt T, Zhang X, Wiesenfeld-Hallin Z (1994) Messenger plasticity in primary sensory neurons following axotomy and its functional implications. Trends Neurosci 17:22-30.

Holmes FE, Mahoney S, King VR, Bacon A, Kerr NC, Pachnis V, Curtis R,
Priestley JV, Wynick D (2000) Targeted disruption of the galanin gene reduces the number of sensory neurons and their regenerative capacity. Proc Natl Acad Sci USA 97:11563-11568.

Howard AD, Tan C, Shiao LL, Palyha OC, McKee KK, Weinberg DH, Feighner SD, Cascieri MA, Smith RG, Van Der Ploeg LH, Sullivan KA (1997) Molecular cloning and characterization of a new receptor for galanin. FEBS Lett 405:285-290.

Jacoby AS, Holmes FE, Hort YJ, Shine J, Iismaa TP (2002) Phenotypic analysis of Galr1 knockout mice reveals a role for GALR1 galanin receptor in modulating seizure activity but not nerve regeneration. Lett Pept Sci 8:139-146.

Kerr BJ, Cafferty WB, Gupta YK, Bacon A, Wynick D, McMahon SB, Thompson SW (2000) Galanin knockout mice reveal nociceptive deficits following peripheral nerve injury. Eur J Neurosci 12:793-802.

Liu HX, Brumovsky P, Schmidt R, Brown W, Payza K, Hodzic L, Pou C, Godbout C, Hokfelt T (2001) Receptor subtype-specific pronociceptive and analgesic actions of galanin in the spinal cord: selective actions via GalR1 and GalR2 receptors. Proc Natl Acad Sci USA 98:9960-9964.

Ma W, Bisby MA (1997) Differential expression of galanin immunoreactivities in the primary sensory neurons following partial and complete sciatic nerve injuries. Neuroscience 79:1183-1195.

Ma X, Tong YG, Schmidt R, Brown W, Payza K, Hodzic L, Pou C, Godbout C, Hokfelt T, Xu ZQ (2001) Effects of galanin receptor agonists on locus coeruleus neurons. Brain Res 919:169-174.

Marti E, Gibson SJ, Polak JM, Facer P, Springall DR, Van Aswegen G, Aitchison M, Koltzenburg M (1987) Ontogeny of peptide- and aminecontaining neurones in motor, sensory, and autonomic regions of rat and human spinal cord, dorsal root ganglia, and rat skin. J Comp Neurol 266:332-359.

Mennicken F, Hoffert C, Pelletier M, Ahmad S, Walker P, O'Donnell D (2001) Distinct distributions of GALR1, GALR2 and GALR3 mRNAs in the adult rat CNS and their modulation in pain models. Soc Neurosci Abstr 27:148.6.

Murphy PG, Grondin J, Altares M, Richardson PM (1995) Induction of interleukin-6 in axotomized sensory neurons. J Neurosci 15:5130-5138.

Murphy PG, Ramer MS, Borthwick L, Gauldie J, Richardson PM, Bisby MA (1999) Endogenous interleukin-6 contributes to hypersensitivity to cutaneous stimuli and changes in neuropeptides associated with chronic nerve constriction in mice. Eur J Neurosci 11:2243-2253.

Nahin RL, Ren K, De Leon M, Ruda M (1994) Primary sensory neurons exhibit altered gene expression in a rat model of neuropathic pain. Pain 58:95-108.

Ogren SO, Pramanik A, Land T, Langel U (1993) Differential effects of the putative galanin receptor antagonists M15 and M35 on striatal acetylcholine release. Eur J Pharmacol 242:59-64.

O'Meara G, Coumis U, Ma SY, Kehr J, Mahoney S, Bacon A, Allen SJ, Holmes F, Kahl U, Wang FH, Kearns IR, Ove-Ogren S, Dawbarn D, Mufson EJ, Davies C, Dawson G, Wynick D (2000) Galanin regulates the postnatal survival of a subset of basal forebrain cholinergic neurons. Proc Natl Acad Sci USA 97:11569-11574.

Patrone C, Andersson S, Korhonen L, Lindholm D (1999) Estrogen receptor-dependent regulation of sensory neuron survival in developing dorsal root ganglion. Proc Natl Acad Sci USA 96:10905-10910.

Rivera-Bermudez MA, Bertics PJ, Albrecht RM, Mosavin R, Mellon WS (2002) 1,25-Dihydroxyvitamin $\mathrm{D}_{3}$ selectively translocates PKCalpha to nuclei in ROS 17/2.8 cells. Mol Cell Endocrinol 188:227-239.

Scott MK, Ross TM, Lee DH, Wang HY, Shank RP, Wild KD, Davis CB, Crooke JJ, Potocki AC, Reitz AB (2000) 2,3-Dihydro-dithiin and -dithiepine-1,1,4,4-tetroxides: small molecule non-peptide antagonists of the human galanin hGAL-1 receptor. Bioorg Med Chem 8:1383-1391.

Smith KE, Walker MW, Artymyshyn R, Bard J, Borowsky B, Tamm JA, Yao WJ, Vaysse PJ, Branchek TA, Gerald C, Jones KA (1998) Cloned human and rat galanin GALR3 receptors: pharmacology and activation of G-protein inwardly rectifying $\mathrm{K}^{+}$channels. J Biol Chem 273:23321-23326.

Sten Shi TJ, Zhang X, Holmberg K, Xu ZQ, Hokfelt T (1997) Expression and regulation of galanin-R2 receptors in rat primary sensory neurons: effect of axotomy and inflammation. Neurosci Lett 237:57-60.

Suburo AM, Gu XH, Moscoso G, Ross A, Terenghi G, Polak JM (1992) Developmental pattern and distribution of nerve growth factor lowaffinity receptor immunoreactivity in human spinal cord and dorsal root ganglia: comparison with synaptophysin, neurofilament and neuropeptide immunoreactivities. Neuroscience 50:467-482. 
Tham S, Dowsing B, Finkelstein D, Donato R, Cheema SS, Bartlett PF, Morrison WA (1997) Leukemia inhibitory factor enhances the regeneration of transected rat sciatic nerve and the function of reinnervated muscle. J Neurosci Res 47:208-215.

Thompson SW, Priestley JV, Southall A (1998) gp130 cytokines, leukemia inhibitory factor and interleukin-6, induce neuropeptide expression in intact adult rat sensory neurons in vivo: time-course, specificity and comparison with sciatic nerve axotomy. Neuroscience 84:1247-1255.

Verge VM, Xu XJ, Langel U, Hokfelt T, Wiesenfeld-Hallin Z, Bartfai T (1993) Evidence for endogenous inhibition of autotomy by galanin in the rat after sciatic nerve section: demonstrated by chronic intrathecal infusion of a high affinity galanin receptor antagonist. Neurosci Lett 149:193-197.

Villar MJ, Cortes R, Theodorsson E, Wiesenfeld-Hallin Z, Schalling M, Fahrenkrug J, Emson PC, Hokfelt T (1989) Neuropeptide expression in rat dorsal root ganglion cells and spinal cord after peripheral nerve injury with special reference to galanin. Neuroscience 33:587-604.

Wang S, He C, Hashemi T, Bayne M (1997) Cloning and expressional characterization of a novel galanin receptor: identification of different pharmacophores within galanin for the three galanin receptor subtypes. J Biol Chem 272:31949-31952.

Wang S, Hashemi T, Fried S, Clemmons AL, Hawes BE (1998) Differential intracellular signaling of the GalR1 and GalR2 galanin receptor subtypes. Biochemistry 37:6711-6717.

Waters SM, Krause JE (2000) Distribution of galanin-1, -2 and -3 receptor messenger RNAs in central and peripheral rat tissues. Neuroscience 95:265-271.

Wiesenfeld-Hallin Z, Xu XJ, Villar MJ, Hokfelt T (1989) The effect of intrathecal galanin on the flexor reflex in rat: increased depression after sciatic nerve section. Neurosci Lett 105:149-154.

Wiesenfeld-Hallin Z, Xu XJ, Langel U, Bedecs K, Hokfelt T, Bartfai T (1992) Galanin-mediated control of pain: enhanced role after nerve injury. Proc Natl Acad Sci USA 89:3334-3337.

Wiesenfeld-Hallin Z, Xu XJ, Hao JX, Hokfelt T (1993) The behavioural effects of intrathecal galanin on tests of thermal and mechanical nociception in the rat. Acta Physiol Scand 147:457-458.

Wittau N, Grosse R, Kalkbrenner F, Gohla A, Schultz G, Gudermann T (2000) The galanin receptor type 2 initiates multiple signaling pathways in small cell lung cancer cells by coupling to $G_{q}, G_{i}$ and $G_{12}$ proteins. Oncogene 19:4199-4209.

Wynick D, Hammond PJ, Akinsanya KO, Bloom SR (1993) Galanin regulates basal and oestrogen-stimulated lactotroph function. Nature 364:529-532.

Wynick D, Small CJ, Bacon A, Holmes FE, Norman M, Ormandy CJ, Kilic E, Kerr NC, Ghatei M, Talamantes F, Bloom SR, Pachnis V (1998) Galanin regulates prolactin release and lactotroph proliferation. Proc Natl Acad Sci USA 95:12671-12676.

Zhong J, Dietzel ID, Wahle P, Kopf M, Heumann R (1999) Sensory impairments and delayed regeneration of sensory axons in interleukin-6deficient mice. J Neurosci 19:4305-4313. 